\title{
Dependent or breadwinner? Vietnamese brides reshaping gender roles at the China-Vietnam border
}

Pengli Huang

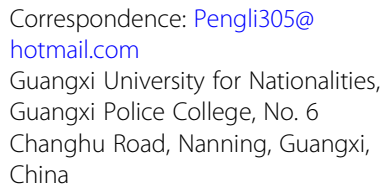

Guangxi University for Nationalities, Guangxi Police College, No. 6 Changhu Road, Nanning, Guangxi, China

\begin{abstract}
Within cross-border marriages, foreign brides' economic contributions to their families are often underestimated due to the fact that they are always believed to be passport and economic "dependents." However, this paper examines how the Vietnamese brides take advantage of their cross-border marriage and migration to China to create more opportunities and social capitals for themselves and their families. Importantly, the specific context of the China-Vietnam border has provided varied opportunities and resources for these women to go beyond the state's regulations and constraints and to experiment with the alternatives. By taking advantage of the prosperity of border trade, the chaotic administration, and the benefits of living in the space "in-between," Vietnamese brides have developed different transnational networks, making concrete contributions to their families and greatly challenging the label of economic "dependents" or family burdens.

Keywords: Vietnamese brides, Cross-border marriage, China-Vietnam border, Gender roles
\end{abstract}

\section{Introduction}

The China-Vietnam border is currently experiencing rapid modernization. With the development and prosperity of cross-border trade, business, and tourism, large numbers of people flow to the border areas to seek opportunities. The bianmaore (border-trade fever) was clearly apparent in many border communities that I visited. More and more new Border Trade Zones had been built or were under construction with investment from either invested governments or transnational economic entities. Legendary stories about people making big money through border trade circulated widely.

As a result of this rapid modernization, one can easily observe the $l u a n^{1}$ (chaos) at the border areas. Many factors have contributed to this chaos. First of all, crossing the border is relatively low-risk and low-cost. The border is easily penetrable and can be crossed by various means. Second, the bianmaore has attracted a large number of people to the border areas for the opportunity they believe it presents. Grillot (2012) points out that luan is caused by the influx of people from diverse places, particularly from the social margins. Continuing movement further complicates the chaotic situation. Additionally, the loopholes in bureaucratic systems and the uneven implementation of state regulations on border control $^{2}$ have encouraged many risk-taking attitudes and activities. The line between legality and illegality is sometimes blurred,

(c) The Author(s). 2017 Open Access This article is distributed under the terms of the Creative Commons Attribution 4.0 International License (http://creativecommons.org/licenses/by/4.0/), which permits unrestricted use, distribution, and reproduction in any medium, provided you give appropriate credit to the original author(s) and the source, provide a link to the Creative Commons license, and indicate if changes were made. 
and many illegal activities, such as small-scale smuggling, ${ }^{3}$ informal border crossings, and unregistered cross-border marriage, ${ }^{4}$ are publicly observable. Corruption among border officials is also very common. ${ }^{5}$

Over the course of my fieldwork in border communities, I found that people there were not only used to the unsystematic development but also acted to maintain the somewhat chaotic situations. One informant commented that different groups of people had various survival skills, and the situations of luan satisfied the needs of many stakeholders who depended on the border for their livelihood and opportunities. Thus, there was an intricate balance and management of chaos and stability, and many people's ultimate goal was to zhuan(da)qian (make (big) money). As local people vividly expressed it, "luanshi chu yingxiong" (the hero is made in a chaotic era).

Among different groups of opportunity seekers, Vietnamese women's figures are prominent. As Grillot observed, at the border areas, "Vietnamese women occupy the immediate border space in a temporary but active manner, and their energy fills the streets' atmosphere" (Grillot 2013:117). Many are independent movers and cross the border frequently, and they also play important and active roles in the local labor market. These Vietnamese women not only develop bilingual and multi-lingual skills through frequent interactions with Chinese people, but many also develop long-term and stable marital or intimate relationships with Chinese men. Cross-border businessmen and bosses like to hire Vietnamese women, particularly those in cross-border marriage, because they consider these women to be more dependable and worthwhile. More importantly, they can pay less to hire a bilingual Vietnamese woman than to hire a Vietnamese man or a Chinese worker for the same amount of work.

Today, there are growing numbers of Vietnamese women making a living at the border areas (Qin et al., 2013). At the same time, "in the borderland, with the open border and the availability of Chinese men, (Vietnamese) women have had a different choice of husbands. Getting married across the border has been part of women's attempt to pursue personal happiness" (Chan 2013:117). However, despite the increase in cross-border marriages and the obvious role of Vietnamese women in economic productions and activities, there are always negative images and reports associated with them in China. These women are believed to be economic dependents who cannot contribute financially, increasing their family's financial burdens and lowering down their quality of life. Furthermore, cross-border marriages are also considered to cause many social problems, such as illegal migration, undocumented workers, trafficking, and cheating marriages.

Contrary to the negative reports of Vietnamese brides, when doing fieldwork, I often heard positive comments about them. A regular comment was that they were nenggan (capable). In the traditional definition, nenggan refers to a wife's excellent ability to manage household chores and duties. However, in conversations with many border residents, I found that in addition to the traditional definition, nenggan is also associated with Vietnamese brides' ability to make money. At present, Vietnamese brides with this quality are popular in the border communities because they are not only good housekeepers but also skilled at making money. The finding was in stark contrast to the images shaped in the mainstream narratives. This contrast thus triggered my interest in paying attention to Vietnamese brides' economic abilities and contributions when studying cross-border marriage in the China-Vietnam borderlands. 
The aim of this paper is to explore how the Vietnamese brides have made concrete contributions to their families and reshaped their gender roles in the context of China-Vietnam borderlands. Are Vietnamese brides country bumpkins who are so ignorant of the rapid development of borderlands? How do they go through the modern transformations and participate in the processes? In what ways have they challenged their gender roles and status within the domestic sphere? These are important questions that this paper intents to answer. Overall, I argue that the development of borderlands has brought many new opportunities and more and more Vietnamese women take part in different economic activities at the borderlands. Moreover, the situations of luan enable them to gain profits. For example, many Vietnamese women are not only able to cross the border (sometimes illegally) with low cost and low risk, but also to engage in small-scale smugglings or to work illegally. Particularly, contrary to the public's belief that Vietnamese brides are economic dependents or family burdens, the informants in this study have indicated different levels of economic capacities, and their contributions to their families and their statues within their families have also increased significantly, though less recognized by the public.

\section{The unnoticed economic contributions of foreign brides}

The acceleration of migration has become one of the salient features of recent years, and economic factors are often framed as the driving force behind the movement of people. As migration has become a global phenomenon, the feminization of migration (Piper 2004; Lan 2008a; Cheng 2010; Thapan 2008; Ehrenreich and Hochschild 2002) is an even more significant but less explored topic. For example, it was not until recently that international statistics on migration began to include data by gender (Zlotnik 2003; Lan 2008a). According to many scholars (Constable 2003, 2009; Piper 2004; Yamanaka and Piper 2005; Jones and Shen 2008; Palriwala and Uberoi 2008), gender not only helps to understand women's role in migration, but even migration itself is a gendered phenomenon. As Thapan states, "While viewing women migrants as dependents, we may often ignore their individual economic contributions, and an analysis based solely on official figures would give an inadequate account of the actual migration flows pertaining to women" (Thapan 2008:10). It is therefore necessary to uncover the gender bias that devalues foreign brides ${ }^{6}$ economic roles and capabilities and to apply a new perspective and logic to understand their agency and contributions.

Many researchers find that negative impressions of foreign brides are common in public constructions (Hsia 2010; Wang and Chang 2009). In many official records, we can only see that the majority of foreign brides migrate legally as dependents rather than as independent passport holders. The status of passport dependent greatly restricts their ability to work. Their passport dependent status thus contributes to their images as financially "dependent" on their husbands and families. Moreover, the gendered norm of nanzhuwai and nüzhunei (men outside, women inside) not only confines women within the domestic sphere but also devalues women's reproductive labor (Lan 2008a, 2008b). Furthermore, within the traditional patriarchal family system, married-out daughters are believed to be pochuqudeshui (spilt water ${ }^{7}$ ) and of no economic value to their birth parents (Zhang 2009). Thus, foreign brides are often seen as "economic dependents," "no-income housewives," and "spilt water," and their money-making abilities and financial contributions to their in-law families and natal families have been largely unrecognized. 
Gender-biased dichotomies, such as public vs. domestic, formal vs. informal, and productive vs. reproductive, have led to the devaluation and underestimation of foreign brides' economic contributions in many ways. When examining women's migration and cross-border marriage experiences, we can find that more and more female migrants become independent movers and capable breadwinners and that they are the ones who take the initiative to move across the border, seeking benefits for their families (Piper 2004; Yamanaka and Piper 2005). Although more and more migrant women have participated in economic activities, the gendered labor division has not been substantially altered (Zuo 2004; Zuo and Bian 2005) and they are still not seen as real breadwinners.

Moreover, within a patriarchal citizenship system, the passport dependent status of foreign brides excludes from the formal labor market. At the same time, family responsibilities also force them to engage more in part-time jobs rather than in full-time employment (Bélanger and Linh 2011). Therefore, many foreign brides generally work in the informal service sectors or choose to work illegally, outside the scope of official statistics (Piper 2004). These undocumented migrant labors also risk serious punishment if caught (Thi et al., 2008).

Sometimes, the nature of family-run businesses hides the economic contributions of foreign brides. For example, some researchers (Lan 2008a; Wan et al., 2013) find that many foreign brides, by taking advantage of their foreigner identity, help their husband's families to open exotic restaurants or shops. Although the foreign brides are the real managers, the businesses are often registered under the names of their husbands. Although many foreign brides make similar or even more contributions to family businesses, their husbands are always considered the "real heads" of the businesses and the qualified breadwinners.

Furthermore, financial supports from foreign brides to their natal families have also been under-acknowledged due to the traditional gender norm of seeing married-out daughters as "spilt water" (Zhang 2009). However, as noted by many scholars (Suzuki 2005; Angeles and Sunanta 2009; Cheng 2010), with the improvement of migrant women's economic capabilities, they are more likely to help their parents with concrete supports. Migrant daughters are more reliable than sons in remitting income to their birth families (Angeles and Sunanta 2009; Faier 2007; Mills 1999; Lapanun 2010). Interestingly, some studies (Bélanger and Linh 2011; Suzuki 2005) discover that even when a foreign bride earns money by herself and sends remittance home, their parents and relatives still believe that the financial support is from the son-in-law. Here, we can easily discern how the stereotypical gendered bias to see foreign brides only as dependents works again to deny their economic contributions.

Nevertheless, foreign brides are not simply the victims of gender norms, because these women can also reshape their gender roles simultaneously within the domestic, informal, and reproductive regimes (Tanabe and Tokita-Tanabe 2003). Often, their transgressive practices are not carried out through public campaigns or political movements. Instead, women have incorporated the potential for resistance and change into their daily life activities. "Women in transnational marriages are 'transmigrants' who, through their everyday activities, develop and maintain multiple relationships-familial, economic, social, organizational, religious, and political-that span borders." (Angeles and Sunanta 2009:552). Although this kind of agency is less recognized in the man-dominated system and also makes no significant changes to existing gender norms, it is crucial to foreign brides' lives and self-empowerment. 
With the increase in cross-border marriage between China and Vietnam, the phenomenon of Vietnamese brides has attracted more and more public attention and discussions. Some researchers (Chan 2013; Grillot 2012, 2013) have observed new models of transnational intimate alliances that "can enhance one's economic opportunity in the life of the borderland" (Chan 2013:113). However, what has been lacking from these researchers' analyses is an examination of what Vietnamese women's roles within the operations are. Beyond their negative images as "economic dependents," "unproductive housewives," and "spilt water," we still lack knowledge about how they exert their agency through hidden economic contributions and daily life activities, which has automatically carry implications of transgression.

\section{The specific research context of China-Vietnam border}

The borderland is an important context in my study. "Border towns have a particularly significant position in terms of migration and transition. People come, return, end up, exchange, pass by and/or settle in these places, irrespective of whether they originated from rural or urban regions or of the purpose of their initial projects" (Grillot 2013:82). With the prosperity of border trade and the development of ASEAN (Association of Southeast Asian Nations), the Chinese and Vietnamese governments have cooperated to create certain special economic zones along the frontier. The model of a "Border Economic Corridor" is coming into being to connect parallel villages, towns, and cities in neighboring countries through their border. The "Nanning-the Friendship PortHanoi" "economic corridor" is one of the sites where I carried out my fieldwork.

Many special policies for cross-border trade and businesses, tourism, and communications have been implemented along the economic corridors. Border Trade Zones and Tax-Reservation Zones have been built along the border. The situations of "in-between-ness" (Bao 2005; Lyons and Ford 2008) or liangguo yicheng (two countries, one city) are quite apparent in these areas. Within the border zones, traders and businessmen from both countries are able to invest and carry out economic activities directly, and cross-border mobility-such as for tourism, education, marriage, and family visiting-is common. However, the development of the borderlands is proceeding in an unsystematic manner and the administrations there are also very disorganized. Thus, it is difficult to use traditional definitions of the rural and the urban to describe the demographic backgrounds of many informants in this study. For example, some Border Trade Zones are located in a rural area but have become very advanced and urbanized, and many residents there have in fact come from the cities; at the same time, some informants I met in the cities used to live in villages or small towns and later moved to and settled in the big cities. Often, traveling frequently across the border or between the rural and the urban has become part of the reality of life for many people living in these "in-between" spaces.

I carried out my fieldwork mainly in 2011 and 2012. Along the "Nanning-Friendship Port-Hanoi" Economic Corridor, Nanning and Hanoi were the main locations where I collected data on cross-border marriages. Another important research site were the several Border Trade Zones and neighboring villages around the Friendship Port. The Border Trade Zones I visited used to be villages along the border and later were developed into special economic areas. Usually, businessmen and tourists from different places in both Vietnam and China are easily identifiable at the Border Trade Zones. Many local people are working 
in these zones during the day and go back to their home in the nearby villages at night. Some from relatively faraway villages and towns will stay in the zones much longer and only visit home during holidays. Beside these formal trade zones, there are also many informal open markets formed by border residents for daily life and small-scale transactions.

Altogether, I interviewed 29 Vietnamese women in different types of cross-border relationships, all of whom had met or married their Chinese husbands after the re-opening of the border in 1991. The majority I met lived and worked in China and most had moved towards their husband. Although many of these women kept moving back and forth over the border before and after their marriages, about three quarters of the informants spent more time in China during the interview period. My research design went beyond the narrow focus on unregistered cross-border marriages and the "mono-site" ethnographies of many previous Chinese researchers. I noticed that along the borderline, cross-border intimate encounters happened across various "contact zones." Thus, I traveled to different border cities, towns, trade zones, and villages to meet Vietnamese brides and tried to identify varied cross-border intimacies. I took note of any possible sources of information concerning my research topic, and I followed these clues to different sites to collect data, such that my travel was often directed by the new information that emerged the interview process.

The informants were involved in various types of cross-border intimacies with Chinese men. Some women who first migrated for job opportunities and then married Chinese men, and others migrated for marriage. Some registered their marriages, but others did not; some lived in cities, while others lived in villages; and some resided on the Chinese side of the border and others on the Vietnamese side. The situation of Vietnamese brides even varied from case to case for those who lived in the same community.

Unlike the one-directional migration described by many Chinese scholars, frequent border crossings between the countries were not only a reality of life for many of these women but also a strategy for survival and development. Similarly, the mobility of Vietnamese women and Chinese men has been increasingly bidirectional and circular. No doubt existing geographic and regional divisions were set up for the purpose of official administration; however, increasing national and transnational mobility has further blurred the boundaries between different locations. Informants in different locations showed diverse ways of adapting to or resisting formal changes in law and policy.

Although my research was focused on how these cross-border intimacies were formed, understanding how Vietnamese brides make a living was also an important aspect of my interviews. Contrary to the construction of foreign brides as passport dependents who have to rely on their husbands and who lack economic skills and independence, most informants contributed equally or even more to family incomes compared to their husbands. The informants were from different social backgrounds (see Table 1 below). ${ }^{9}$ Only three informants-Fangcui, Aling, and Shulan-had stable and formal jobs. Other informants engaged in the informal economy or self-employment, which means these Vietnamese brides' economic activities and contributions were easily underestimated.

\section{Findings and analyses}

\section{The lures of mobility: feminizing the borderlands}

After the China-Vietnam border was reopened in the early 1990s, the first people to develop the new territory were various "traders." The 1990s were characterized by a rapid 
Table 1 Profile of the research participants' occupational backgrounds

\begin{tabular}{|c|c|c|c|c|c|c|c|}
\hline No. & Pseudonym & Age & Occupation & No. & Pseudonym & Age & Occupation \\
\hline 1 & Apan & 45 & Manual work & 16 & Ahua & 20 & Manual work \\
\hline 2 & Axian & 55 & Farmer & 17 & Shixian & 24 & Self-employment \\
\hline 3 & Xiaolu & 27 & Manual work & 18 & Meigang & 36 & Housewife \\
\hline 4 & Simei & 34 & Family business & 19 & Acai & 28 & Housewife \\
\hline 5 & Xiaomei & 23 & Housewife & 20 & Fangcui & 28 & Teacher \\
\hline 6 & Feifei & 64 & Housewife & 21 & Aling & 28 & Office work \\
\hline 7 & Ayong & 23 & Family business & 22 & Bixiang & 42 & Housewife \\
\hline 8 & Shixiang & 48 & Farmer & 23 & Mingfang & 33 & Family business \\
\hline 9 & Shilan & 44 & Housewife & 24 & Yunyun & 25 & Self-employment \\
\hline 10 & Dingxuan & 35 & Manual work & 25 & Meining & 21 & Manual work \\
\hline 11 & Anni & 36 & Translator & 26 & Mengqiu & 36 & Housewife \\
\hline 12 & Falang & 38 & Family business & 27 & Jiali & 22 & Housewife \\
\hline 13 & Lushi & 47 & Farmer & 28 & Shulan & 48 & Accountant \\
\hline 14 & Liuyi & 43 & Manual work & 29 & Jiayuan & 24 & Housewife \\
\hline 15 & Tianzheng & 40 & Family business & & & & \\
\hline
\end{tabular}

expansion of bianmaore (border-trade fever), which made the border an important economic resource for local people (Huang 2012). Crossing the border to sell goods for a better price or to buy cheaper products or services also became a usual practice in the China-Vietnam borderlands. According to the statistics, about $70 \%$ of Vietnamese people who cross into China on a daily basis are business people (Tian et al., 1995). Among these 70\%, more than two thirds are female. For example, one famous business group at the border is formed by 19 Vietnamese women. They have clear labor divisions and engage in cooperative teamwork, as they are keen for business opportunities. Their businesses have covered a wide range of fields and have earned at least 3000 RMB per day per person (Tian and Ye 2005).

More than half of the Vietnamese people who come to the border for opportunities are women. Don't look down upon these women. They are very familiar with the markets and take up considerable market share (Falang).

Vietnamese women are not afraid of hardship and difficulties. Although many are poor and cannot invest a lot when doing business, women are more patient and better at bargaining (than men), so they are able to earn money even in those petty trades. Besides, (Vietnamese) women are good language learners and develop their Chinese quickly in their daily interactions. Hence the majority of translators for border trades are women (Dingxuan).

At the Border Trade Zones, Vietnamese women's figures are everywhere, including those dalaoban (grand bosses) and kuli (laborers). I think Vietnamese women are tough and we are diligent and able to chiku (eat bitterness). Often, we are more responsible, careful and efficient than men. So the bosses like to hire Vietnamese women more than men (Liuyi). 
Now the China-Vietnam border is in a golden development time, and there are so many opportunities here and also the need for a large labour force. I came to the border not just because it is easier to find a job here, but I also wanted to learn and improve my Mandarin. The potentials for cross-border trade are huge; however if you want to grasp the shangji (business opportunities), you must be familiar with both markets. The borderland is like an experimental base for making some tests. To hundehao (make a good life) here, you need to master bilingual fluency. If you are bilingual speaker, you will be quite popular in the labour market and can easily access more profitable jobs and acquire more income sources (Ayong).

In the process of seeking job opportunities in China, a Vietnamese woman becomes "an entrepreneur of oneself, maximizing himself or herself as "human capital"' (Lazzarato 2009:111). Among different migrant Vietnamese women, kaozhe bianjing chi bianjing (depending on/taking advantage of the border) has been both a reality of life and a development strategy. They also access the border through different means and networks. Some (e.g., Liuyi, Dingxuan, Xiaolu, Falang) initially entered China informally and did not have a legal status in China in the early 1990s. Later, with the influx of migrant population, those who came later as migrant workers (e.g., Ayong, Anni) were more likely to cross the border with passports, although they may not have held a valid working visa in China. In the meantime, the rapid development of China-Vietnam trade and economic cooperation also triggered a fever of educational exchange between the two countries. Many informants (e.g., Yunyun, Shixian, Fangcui) chose to be foreign students in China with the hope of better employment potential in the future. Although they came from different family backgrounds and held different types of social capital, all the women were more or less integrated in or actively took part in the project of modernization around the border.

Feifei was among the first group of women who came to the border for new opportunities right after its re-opening. Her first attempt turned out to be a failure, and her money was taken away by her business co-partner. Luckily, she met her Chinese husband who provided not only shelter but also financial support for her children left behind in Vietnam. After that, Feifei began to cooperate with her sisters in Vietnam to bring some welcome commodities from China to Vietnam to sell. According to Feifei, what she did was xiaobenshengyi (small-investment business), because like most other Vietnamese women, she was not as brave as men and also did not have much money to invest. Besides, this type of small-scale smuggling would not be targeted by the local authorities. Feifei said that although she did not make big money like some others, she felt satisfied with her small business and believed that she came to the border at a good time. With her husband's help and the money she earned from her business, she was able to support her six children in Vietnam through to adulthood.

Anni was 36-years-old and worked as a translator in Nonghuai. ${ }^{10}$ She went to China in 2010. Before that, she worked in Hong Kong for 5 years as a waitress in a small restaurant. She explained that "work is hard there and I could not see any future to get promotion," adding that "although the salary here is not very high, but the job (as translator) is much more decent and I also have more freedom." Anni learned to speak Mandarin and Cantonese by herself, so she was able to find job opportunities with relatively little effort. The place where she worked in China was close to her hometown, and she went home to Vietnam very often; while when working in Hong Kong, she 
only visited home once or twice a year. In Anni's eyes, the borderland, which used to be a remote and backward region, has now become a new land for development. "As long as people can find money and opportunities near their homes, no one wants to travel so far away from home to make a living," she commented.

These Vietnamese brides' stories indicated a key link between the "enterprising subject" (Lyttleton et al., 2011) and the strong desire for development. At the periphery of the China-Vietnam border, Vietnamese women join in these modernization projects and share local discourses in terms of what constitutes personal success based on a number of facilitating factors. First, the rapid development of the border and relatively low cost and risk to cross the border provides greater autonomy for them. Second, the influx of people from both China and Vietnam provides an abundance of information for finding work, organizing transport, transferring money, and forming alliances. Third, women increasingly decide, sometimes independently, to choose to be migrant workers in China rather than working on the farm. Lastly, achieving material success is prominent in Vietnamese brides' perception of the "enterprising self." Underpinning these women's narratives is the manner through which liberalizing economic structures permit the development of an "enterprising subject." On the one hand, the reopening of the border provides new opportunities and interactions for many Vietnamese women; on the other hand, Vietnamese women also take active roles in reshaping the landmarks of the borderlands and announce the rise of niangzijun (women army) in the region.

\section{Hezi hunyin ("joint venture" marriages): blurring the boundaries between housekeeper and breadwinner}

When talking about doing business, I am better than my husband. He is not good at communication and does not know how to bargain with the clients. Like housework, doing business also needs a lot of skills and patience (Tianzheng).

Although I enjoy my current (teaching) job very much, my husband plans to open his cross-border business company in the future and I will choose to help him if necessary (Fangcui).

As I know, many Vietnamese brides play key roles in doing business. However, they know how to save the face for their husbands and attribute the gonglao (credits) to their men. Thus, many Chinese men like to marry a Vietnamese wife (Simei).

We are fuqidian (the husband-wife shop) and manage the restaurant together. There are no clear divisions of labor between us. Sometimes I cook in the kitchen and sometimes also deal with customers in the dining room. It depends on the customers since we have both Chinese and Vietnamese customers. They like to call me laobanniang ${ }^{11}$ (the wife of the boss) (Ayong).

James Farrer (2008) noticed a new cooperative pattern of international marriages between Western men and Chinese women in Shanghai. In his fieldwork, Farrer points out that resource exchanges between these couples are increasingly two-way rather 
than the husbands being the "airplane tickets" for their wives. Farrer adopts a vivid Chinese expression—hezi hunyin ("joint venture" marriages) - to address this new type of international relationship. Forms of hezi hunyin ("joint venture" marriages) were also clearly evident in the lives of many of my informants. Although some informants did not participate directly in the management of their husbands' businesses, their connections with Vietnam were important social, economic, and cultural resources for their husbands' progress in Vietnam. For informants such as Fangcui, Meigang, Bixiang, and Jiali, although they did not engage in their husbands' businesses, their husbands needed to depend on their Vietnamese identities to avoid heavy taxes when opening a foreign company in Vietnam. Therefore, the legal representatives of their husbands' companies were registered under their wives' IDs. The family properties they purchased in Vietnam were also in the names of the wives.

Some wives, like Simei, Tianzheng, Jiayuan, Mingfang, Falang, and Ayong, took an active role in engaging in trade and family businesses. Simei met her husband while doing business at Puzai. ${ }^{12}$ Both her birth family and her husband's family had engaged in border trade before their marriage. Their marriage had helped to connect the respective family networks and greatly increased their chances in the market. The connections between these families also became much stronger. Similarly, Jiayuan was the only child in a business family in Hanoi. She met her husband while studying in Nanning. Her husband was also from a business family, and as the only son, he inherited the family business after graduating from a university. After marriage, Jiayuan's husband persuaded her to take care of the family business with him together instead of working as a tourist guide, since he thought the job was hard with poor pay. Later, after consulting her parents, Jiayuan and her husband opened a new clothing business in Hanoi. The business on the Vietnamese side went well with the help of Jiayuan's mother. The business networks of both the husband's family and Jiayuan's parents expanded greatly.

In their family business responsibilities, Falang and Tianzheng played a more important role than their husbands. Although the businesses were registered under the husbands' names, Falang and Tianzheng were the real heads. Tianzheng applied for a stall in the local market under her husband's name and sold some needed commodities from China and brought back some cheap-priced goods from Vietnam. Usually, Tianzheng was the one going to the Vietnamese side to choose goods and selling them in the market and her daughter would come to help her during the weekends. As her husband was not as good at communicating with customers as she was, he mainly took care of household chores, such as washing clothes, cooking, and delivering meals to the market. According to Tianzheng, her husband was as busy and working as hard as she was; without his contribution, it would have been difficult for her to run a good business.

Although the couples in this study may not be as prosperous and educated as those in Farrer's (2008) study, the pattern of hezi hunyin also emerged as the chief strategy for my informants to achieve their goals for advancement. The term for "joint venture" marriages echoes those Chinese expressions, like shangjia (business family) or wuqi (family enterprise), which emphasize the family as a corporate entity of family members. Different from Yan's $(2003,2011)$ idea that the corporate model has been finally replaced by the individualized model of family, for many Vietnamese brides in this study, the former model still works better to cater to their needs. Furthermore, within a "joint venture" marriage, the wives are not only able to exert more power ("I am 
better than my husband.") and take more advantage of their "Vietnamese-ness" ("cross-border trades") but also challenge the boundaries between public and private, breadwinner and housekeeper, and home and work ("There are no clear divisions of labor between us").

\section{Remittance: being a capable daughter and transnational bridge builder}

I am happy to be able to support my parents and my siblings. I earn my money and no one can complain when I send money to my parents. My family (in Vietnam) always respects my ideas. Whenever there is a big event, they always call me for suggestions (Xiaomei).

You know, in rural areas, feudal thoughts still prevail and the belief that "a son is better than a daughter" is still popular. I want to show that I am not peiqianhuo (useless) and that I can be better than a son. I want my parents to be proud of me (Ayong).

I will always be the daughter of my parents whether I got married or not. This strong connection will never change. I want to give money to my parents though they do not ask for it. We also send money to his (the husband's) parents. Both sets of parents are equally important (Fangcui).

I am the eldest daughter in the family and don't have a brother. Shouldering family responsibility is tiangjingdiyi (born as nature). My father died when I was still a teenager. Since then, I have always felt that I am a semi-parent of the family. I told my husband before marriage I would not skip my responsibility to support the family (Bixiang).

As Angeles and Sunanta (2009) suggest, remittance has become the new currency of a daughter's duty as women's economic capabilities and social status increase. Many Vietnamese women in the interviews expressed similar ideas in my interviews. Remittance was not only a link between them and their natal families ("This strong connection will never change") but also an indication of the changing status of a daughter ("I am not peiqianhuo," "I can be better than a son," "Both sets of parents are equally important."). At the same time, through making financial contributions to their families, the daughters' roles within their families also improved substantially ("They always call me for suggestions."). As noted by many scholars, migrant daughters are more reliable than sons in remitting income to their birth family (Angeles and Sunanta 2009; Faier 2007; Mills 1999; Lapanun 2010). Some informants, for example, Bixiang and Ayong, had held a strong sense of filial duty as they were each the eldest child in a family without a son. For them, to support the natal family meant not only to be a filial daughter but also to indicate their special status within the family ("I always feel that I am a semi-parent of the family.").

Ayong was from a single-parent family. Her father died when she was still a teenager and her mother had to raise two daughters alone on a tight family budget. To support her widowed mother and younger sister, Ayong did not want to continue her studies after graduating from high school in 2007 and began instead to work at the border. She sent money home often to support the family and her young sister's education. After 
she married her Chinese husband, the couple opened a Vietnamese cuisine restaurant near the Friendship Port. Then, Ayong asked her mother and sister to come together to help with the family business. Falang and her husband ran a busy hair salon at Puzai. She spent a lot of money on building a large house for her family and visited home in Vietnam quite often. Fourteen employees in the hair salon were all from Falang's hometown in Thái Nguyên. In the eyes of her employees, Falang was a successful role model because she started her business from next to nothing. In the hometown, she earned a great reputation for providing many job opportunities to relatives and neighbors.

Geographic proximity and the development of transportation and communication technologies have facilitated these collaborations. Within a transnational context, Vietnamese brides' collaborating with their natal families and kinships brought many advantages for them that most local couples lack. The increase in cross-border marriage has expanded Vietnamese brides' family networks, and these networks can transform into stable and dependable social capitals for both the brides and their families (Huang 2016b). Many informants not only felt proud of their earning ability but also maintained a special status in their birth families: they were no longer "spilt water" but forever daughters of their natal families. The new currency of daughters' filial piety was also welcomed by parents, particularly those who did not have a son. At the same time, with the remittances from the migrant daughters, the parents and siblings also gained more opportunities for development. Reciprocally, this development can help to increase their daughters' status in their husbands' families.

\section{Discussion}

In the borderlands, "what were once tales of deprivation and subjugation of the border have been refigured as compelling narratives of personal gain" (Lyttleton et al., 2011:325). New circumstances require a different understanding of Vietnamese women in the ways that they construct their diasporic identities and the "cultural representation and alternative space which may be less dominant and less visible in the mainstream popular imagination" (Kim 2011:37). As Marc Askew argues, borderlands function "as sites that expose patterns of transgressing against forms of state- and center-defined identity" (Askew 2009:180). Vietnamese brides' cross-border marriages and mobility automatically carry an implication of transgression. Evidently, "border crossings are not driven solely by the pragmatic attractions of the price differences prevailing between countries: when considered as cultural practices, these border crossing movements can be interpreted ethnographically as transgressive and affirming practices" (Askew 2009:180). These transgressive and affirming practices are not carried out through public campaigns or political movements. Instead, Vietnamese brides have incorporated the potential for resistance and change into their daily life activities.

First of all, among different migrant Vietnamese women, kaozhe bianjing chi bianjing (depending on/taking advantage of the border) has been both a life reality and a development strategy. These women have accessed the border through different means and networks. Although they come from different family backgrounds and held different types of social capital, the women are more or less integrated into or take active part in the development of borderlands. More and more Vietnamese women have joined in different economic activities; they have deliberately taken advantage of the in-between spaces and enjoyed the benefits from living a double life in the borderlands. More 
importantly, the borderlands have provided certain spaces for individuals from different social backgrounds and circumstances to cope with their instant realities, not only for the privileged groups.

Moreover, the low cost and low risk of border crossing and the situations of luan have provided different resources and protections for these Vietnamese brides. The rapid but unsystematic development of China-Vietnam border and the uneven administrations breed the situations of luan. This luan has also an impact on reshaping these Vietnamese brides' gender roles. Luan means that there are sometimes blurred lines between legality and illegality, and this situation not only provides some spaces for those women who may find it difficult to follow the rules of the state for their survival, but also caters to their ambition to make money. Many Vietnamese women can take advantage of the loopholes to make profits, and accordingly, the increase of incomes enables them to renegotiate their roles and statuses within the families.

Furthermore, cross-border marriages and family networks create new opportunities for women to challenge these gendered norms. Many women have creatively taken advantage of their cross-border connections to gain more economic opportunities. They play important roles in helping their husbands' businesses, and some even take up significant positions in running family businesses. Often, these foreign brides have developed more connected and supportive relationships with their husbands as they need to share the duties and risks in the businesses together. Although many couples still conform to traditional labor divisions between husbands and wives, some marital relationships have become more equal due to the wives' increasing financial status and contributions to their families. There was no clear labor division between these couples because they had to share the "public" (business) and the "domestic" (household) responsibilities together.

As Yeates (2004) points out, there is a masculinist bias in the studies of migration and globalization, which have privileged the roles of state, market, and productive labor. Traditionally, nanzhuwai, nüzhunei (men outside, women inside) was the gendered norm for labor division between married. Women are expected to become a xiaoshun nüer (filial daughter) and a xianqi liangmu (virtuous wife and good mother), and these gendered expectations restrict them to the domestic sphere (Wolf 1972). Similarly, within a transitional context, foreign brides are always associated with reproductive labors that are devalued as unpaid or low-paid jobs (Lan 2008b; Sheu 2007), even though more and more women participate in the labor market and some are even the real "breadwinners" of their families. In fact, their economic roles and contributions have much transgressed those migration categories such as "marriage," "work," "public," "domestic," "breadwinner," and "housekeeper." However, these changes have not been fully recognized due to gender biases. Thus, many researchers have advocated for "symbolic and interpretive analyses, critical global and feminist perspectives" to carefully examine the "overly binary models of public and private, intimate and impersonal, material and emotional, love and money, local and global, nature and culture" (Constable 2009:57).

Affected by mainstream feminist discourses, many studies on migrant women often emphasize the importance of raising women's consciousness to form political alliances and to make changes through activism. In interviews, I found that the informants showed little interest in attending public organizations and they even tried to distance themselves from politics. However, if we look into these women's micro dynamics and 
the details of lived experiences, we will see the transgressive implications of their practices. This echoes P. S. Y. Ho's argument that "action taken by individuals or small groups of people, without deliberate political agenda or strategy can become part of a larger social movement, sometimes with significant political impact" (Ho 2006:563). Vietnamese brides practice their agency not by participating in collective movements, but through everyday practices of transgression. Daily life is their battlefield, and they not only fight for their families and significant others but also for self, love, dignity, and recognition as a human.

\section{Conclusion}

In face of the rapidly changing world, Vietnamese brides adjust themselves to the precarious and unpredictable future with more flexibility. As one migrant bride comments, "We Vietnamese women are just like houses on the mountain top; when storms come, we open the door and are exposed to wind and rain, confronting and coming through all storms with a peaceful heart" (Mo 2010:43). Contrary to a stereotypical view of Vietnamese brides as "backward," "financial burdens," and "ignorant" of state policies, they show great acumen in taking advantage of the in-between spaces they live in and "negotiating a wide variety of linguistic and cultural circumstances" (Taylor 2007:268). They are not ignorant of the possible hardships and unfairness in life; rather, they are ready for the worst and anticipate the better.

A public vs. domestic dichotomy and a partial emphasis on the public aspect have led to inadequate discussion and recognition of private lives. Women's lives are sites carrying significant political meanings and potential for change; however, these aspects have often been ignored by mainstream studies (Huang 2016a). To better understand Vietnamese brides' lives, it is important to situate these women in the processes of modernization and globalization to examine their struggles and coping strategies. By abandoning an "expert model" to study women, researchers will not miss the complexities of women's life realities and the political implications of their ordinary practices.

\section{Endnotes}

${ }^{1}$ In Chinese, luan can be both a noun (chaos) and an adjective (chaotic).

${ }^{2}$ In Chinese, luan can be both a noun (chaos) and an adjective (chaotic).

${ }^{3}$ For example, to evade tax, laborers are hired in public to carry split cargo across the border via shortcuts.

${ }^{4}$ Today, people are less likely to define unregistered marriage as an illegal behavior because marriage registration is no longer a compulsory state regulation and co-habitation has also become a common social phenomenon, even in rural areas.

${ }^{5}$ At the checkpoint, regular cross-border travelers were familiar with the common practice of bribing officials for an easier and faster check. I was told by friends to put 10 RMB inside my passport to avoid the so-called health check when passing through Vietnamese customs.

${ }^{6}$ In literature review, although using the term "foreign brides," it refers particularly to Vietnamese brides or those brides who are from Southeast Asian countries. Often, Vietnamese brides and those brides who are from Southeast Asian countries share many similarities due to the fact that many Southeast Asian countries are under the deep influence of Confucian and filial cultures. However, the author also notices the difference 
between Vietnamese brides and other brides. Comparably, Vietnamese brides at the China-Vietnam border maintain much more frequent cross-border activities even after they get married and settle down in China.

${ }^{7}$ Spilt water implies the relationship between the married daughter and her natal family is similar to spilt water that cannot be taken back.

${ }^{8}$ Nanning is the capital city of Guangxi Province. Hanoi is the capital of Vietnam and also the central city of Northern Vietnam. This economic corridor is the most convenient way to travel between the two countries. There is an expressway connecting Nanning and Hanoi, and it takes only about 4 to $5 \mathrm{~h}$ of bus trip between the two cities.

${ }^{9}$ In interviews, I talked with most informants in Chinese or local dialects and the informants usually introduced their translated Vietnamese names to me since I was not familiar with Vietnamese spellings. Thus, in this paper, the names of informants are in Chinese pinyin. Moreover, pseudonyms have been used throughout the paper in order to protect informants' privacy.

${ }^{10}$ Nonghuai is one of the prosperous border trade zones on the Chinese side, established in 1989.

${ }^{11}$ Although these informants were usually called as laobanniang (the wife of the boss), they were actually the bosses of family businesses.

${ }^{12}$ Puzai is a famous border trade zone near the Friendship Port.

\section{Acknowledgements}

The author is grateful for the advice of Sik Ying Ho at the University of Hong Kong, and she also wants to express thanks to the Guangxi Police College and Guangxi University for Nationalities for providing supports for further research on this field.

\section{Funding}

This research received funding from the 2017 Guangxi University Teachers Ability-Enhancement Project (No. 2017KY0878).

\section{Author's information}

Pengli Huang received a Ph.D. degree from the University of Hong Kong and was a visiting scholar at the Center for Women's and Gender Studies in University of Texas at Austin, USA. She is currently a post-doc fellow at Guangxi University for Nationalities and an AP at Guangxi Police College, China. Her research field includes cross-border marriage and gender studies.

Competing interests

The author declares that she has no competing interests.

\section{Publisher's Note}

Springer Nature remains neutral with regard to jurisdictional claims in published maps and institutional affiliations.

Received: 2 March 2017 Accepted: 24 October 2017

Published online: 31 October 2017

References

Angeles, Leonora C., and Sirijit Sunanta. 2009. Demanding daughter duty: gender, community, village transformation, and transnational marriages in Northeast Thailand. Critical Asian Studies 41 (4): 549-574.

Askew, Marc. 2009. Sex and the sacred: sojourners and visitors in the making of the southern Thai borderland. In Centering the margin: Agency and narrative in southeast Asian borderlands, ed. by Alexander Horstmann and Reed L. Wadley, 177206. New York, Oxford: Berghahn Books.

Bao, Jiemin. 2005. Marital acts: Gender, sexuality, and identity among the Chinese Thai Diaspora. Honolulu: University of Hawai'i Press.

Bélanger, Danièle, and Tran Giang Linh. 2011. The impact of transnational migration on gender and marriage in sending communities of Vietnam. Current Sociology 59 (1): 59-77.

Chan, Yuk Wah. 2013. Vietnamese-Chinese relationships at the borderlands: Trade, tourism and cultural politcs. New York: Routledge.

Cheng, Sealing. 2010. On the move for love: Migrant entertainers and the U.S. military in South Korea. Philadelphia: University of Pennsylvania Press.

Constable, Nicole. 2003. Romance on a global stage: Pen pals, virtual ethnography, and "mail-order" marriage. Berkeley; Los Angeles; London: University of California Press. 
Constable, Nicole. 2009. The commidification of intimacy: Marriage, sex, and reproductive labor. Annual Review of Anthropology 38: 49-64.

Ehrenreich, Barbara, and Arlie Russell Hochschild. 2002. Introduction. In Global woman: nanies, maids, and sex workers in the new economy, ed. Barbara Ehrenreich and Arlie Russell Hochschild. New York: Henry Holt. 1-10.

Faier, Lieba. 2007. Filipina migrants in rural Japan and their professions of love. American Ethnologist 34 (1): 148-162.

Farrer, James. 2008. From "passports" to "joint ventures": Intermarriage between Chinese nationals and Western expatriates residing in Shanghai. Asian Studies Review 32: 7-29.

Grillot, Caroline. 2012. Between bitterness and sweetness, when bodies say it all: Chinese perspectives on Vietnamese women in a border space. Journal of Vietnamese Studies 17 (1): 106-148.

Grillot, Caroline. 2013. The fringes of conjugality: On fantasies, tactics and representations of Sino-Vietnamese encounters in borderlands, Ph. D dissertation. Amsterdam: Department of Social and Cultural Anthropology, Vrije Universiteit.

Ho, Petula Sik Ying. 2006. The (charmed) circle game: Reflections on sexual hierarchy through multiple sexual relationships. Sexualities 9 (5): 547-564.

Hsia, Hsiao-Chuan. 2010. 2010. Introduction. In For better or for worse: Comparative research on equity and access for marriage migrants, ed. Hsiao-Chuan Hsia, 1-26. Hong Kong: Asia Pacific Mission For Migrants.

Huang, Pengli. 2016a. Vietnamese brides' practices of maternal citizenship at the China-Vietnam border. Asian Women 32 (1): 77-110.

Huang, Pengli. 2016b. Youqian jiuyou haonüer-Yuenan xinniang dui "tiebu niangjia" xingwei de jieshi (money makes a good daughter: Vietnamese Brides' explanations of sending money back to their natal families). Collection of Women's Studies 133 (1): 107-117.

Huang, Yunsi. 2012. Cong biancun dao biancheng: dui Guangxi Pingxiangshi Puzhai de yanjiu ffrom border village to border town: a study on Puzhai in Guangxi Pingxiang City), M.A. thesis. Nanning: College of Ethnic Studies and Sociology, Guangxi University for Nationalities.

Jones, Gavin, and Hsiu-hua Shen. 2008. International marriage in East and Southeast Asia: Trends and research emphases. Citizenship Studies 12 (2): 9-25.

Kim, Youna. 2011. Transnational migration, media and identity of Asian women: Diasporic daughters. New York: Routledge.

Lan, Pei-Chia. 2008a. Migrant women's bodies as boundary markers: Reproductive crisis and sexual control in the ethnic frontiers of Taiwan. Signs 33 (4): 833-861.

Lan, Pei-Chia. 2008b. New global politics of reproductive labor: Gendered labor and marriage migration. Sociology Compass 2 (6): $1801-1815$.

Lapanun, Patcharin. 2010. Transnational marriages of rural Isan women and the local influences. In Revisiting agrarian transformations in Southeast Asia: Empirical, theoretical and applied perspectives. Chiang Mai: RCSD International Conference.

Lazzarato, Maurizio. 2009. Neoliberalism in action: Inequality, insecurity and the reconstitution of the social. Theory, Culture and Society 26 (6): 109-133.

Lyons, L.T., and M. Ford. 2008. Love, sex and the spaces in-between: Kepri wives and their cross-border Jusbands. Citizenship Studies 12 (1): 55-72.

Lyttleton, Chris, Rui Deng, and Nan Zhang. 2011. Promiscuous capitalism meets 'exotic' ethnicity: Intimate aspirations amongst cross-border Chinese Dai. The Australian Journal of Anthropology 22: 314-331.

Mills, Mary Beth. 1999. Thai women in the global labor force: consuming desires, contested selves. New Brunswick: Rutgers University Press.

Mo, Wangchu. 2010. Cong xinniang dao xinyimin nüxing (from brides to new female migrants). Southern Metropolitan Weekly 405 (12): 41-43.

Palriwala, Rajni, and Patricial Uberoi. 2008. Exploring the links: Gender issues in marriage and migration. In Marriage, migration and gender, ed. Rajni Palriwala and Patricial Uberoi, 23-60. New Delhi; Thousand Oaks: Sage Publications.

Piper, Nicola. 2004. Rights of foreign workers and the politics of migration in South-East and East Asia. International Migration 42 (5): 71-97.

Qin, Hongzeng, Jingbo Chen, and Yandan Wei. 2013. Wenhuaxiangrong yu hezuogongxiang—Jiyu zhongjuo guangxi Dshi yuenanji sangong de taolun (cultural integration and cooperative sharing: The discussions on Vietnamese casual labors of Guangzi D city in China). Journal of Guangxi University for Nationalities 35 (2): 111-116.

Sheu, Yea-huey. 2007. Full responsibility with partial citizenship: Immigrant wives in Taiwan. Social Policy and Administration 41 (2): 179-196.

Suzuki, Nobue. 2005. Tripartite desires: Filipina-Japanese marriages and fantasies of transnational traversal. In Cross-border marriages: gender and mobility in transnational Asia, ed. Nicole Constable, 124-144. Philadephia: University of Pennsylvania Press.

Tanabe, Akio, and Yumiko Tokita-Tanabe. 2003. Introduction: gender and modernity in Asia and the Pacific. In Gender and modernity: perspectives from Asia and the Pacific, ed. Yoko Hayami, Akio Tanabe, and Yumiko Tokita-Tanabe, 1-16. Kyoto, Melbourne: Kyoto University Press \& Trans Pacific Press.

Taylor, Philip. 2007. Cham Muslims of the Mekong Delta: Place and mobility in the cosmopolitan periphery. Singapore: NUS Press.

Thapan, Meenakshi. 2008. Series introduction. In Marriage, migration and gender, ed. Rajni Palriwala and Patricial Uberoi, 7-17. New Delhi; Thousand Oaks: Sage Publications.

Thi, Nguyen, Hai Yen, Thanh-Dam Truong, and Bernadette P. Resurreccion. 2008. Gender, class and nation in a transnational community: Practices of identity among undocumented migrant workers from Vietnam in Bangkok. Gender, Technology and Development 12 (3): 365-388.

Tian, Yue, Rongkun Wang, and Zhen Ye. 1995. Laoshan jiaoxia de yuenan nüren (Vietnamese women at the foot of Lao Mountain). Modern Women 10: 34-35,37.

Tian, Yue, and Zhen Ye. 2005. Zhongyue bianmao "meiguibang" ("Rose Group" in China-Vietnam cross-border trade). Around Southeast Asia 5: 52-53.

Wan, Hui, Hong Zhu, and Xuegiong Tang. 2013. Nüxing kuaguo hunyin yimin yanjiu shuping--Yi tanwan de waiji xinniang weili (review of studies on female cross-border marriage migrants: Taking Foreing brides in Taiwan as an example). Collection of Women's Studies 117 (3): 106-114.

Wang, Hong-Zen, and Shu-Ming Chang. 2009. The Commodification of international marriages: Cross-border marriage business in Taiwan and Viet Nam. In Cross-border marriages with Asian characteristics, ed. Hong-Zen Wang and HsinHuang Michael Hsiao, 211-232. Taipei: Taiwan Academia Sinica, Center for Asia-Pacific Area Studies. 
Wolf, Margery. 1972. Women and the family in rural Taiwan. Stanford CA: Stanford University Press.

Yamanaka, Keiko, and Nicola Piper. 2005. Feminized migration in east and Southeast Asia: Policies, actions and empowerment. Swittzerland: UNRISD (United Nations Research Institute for Soical Development).

Yan, Yunxiang. 2003. Private life under socialism: Love, intimacy and family change in a Chinese village, 1949-1999. Stanford: Stanford University Press.

Yan, Yunxiang. 2011. The individualization of the family in rural China. Boundary 38 (1): 203-229.

Yeates, Nicola. 2004. Global care chain: Critical reflections and lines of enquiry. International Feminist Journal of Politics 6: $369-$ 391.

Zhang, Weiguo. 2009. "A married out daughter is like spilt water?" Women's increasing contacts and enhandced ties with their natal families in post-reform rural north China. Modern China 35 (3): 256-283.

Zlotnik, Hania. 2003. The Global Dimensions of Female Migration. Migration Policy Institute. http://www.migrationinformation. org/feature/display.cfm?ID=109. Accessed 11 Dec 2011 .

Zuo, Jiping. 2004. Shifting the breadwinning boundary: The role of men's breadwinner status and their gender ideologies. Journal of Family Issues 25 (6): 811-832.

Zuo, Jiping, and Yanjie Bian. 2005. Beyond resources and patriarchy: Marital construction of family decision-making power in post-Mao urban China. Journal of Comparative Family Studies 36 (4): 601-622.

Submit your manuscript to a SpringerOpen ${ }^{\odot}$ journal and benefit from:

- Convenient online submission

- Rigorous peer review

- Open access: articles freely available online

- High visibility within the field

- Retaining the copyright to your article

Submit your next manuscript at $\boldsymbol{\nabla}$ springeropen.com 